\title{
Three Dangerous Loops of Lipoprotein-Associated Phospholipase A2 Activity on Increasing LDL Atherogenecity
}

\author{
Retno Susilowati 1, Dianggan Sargowo2, Askandar Tjokroprawiro3
}

\begin{abstract}
Background: Hypercholesterolemia is a major classic risk factor for cardiovascular disease; however, there are $35 \%$ $40 \%$ cases of cardiovascular where patients have normal cholesterol levels. Lp-PLA2 is an enzyme that is produced and secreted by macrophages as a response to the lipid peroxide formation, especially the platelet activating factor compound and phosphocholine peroxide. Lp-PLA2 has been correlated with classic risk factor of cardiovascular disease, although that correlation with number of foam cell at early stage of atherosclerosis is not clear yet. This study aims to determine the lipid profiles, oxidation stress markers and Lp-PLA2 levels at three different initial atherogenesis levels.

Methods: This study observed the change of Lp-PLA2, F2-Isp, MDA, TC, LDL, HDL levels in rat serum at three different levels of early atherogenesis; they were Ath-I, Ath-II and Ath-III made on the number of foam cells. The number of cells was observed in all aortic cross sectional surfaces, using the Oil-Red-O staining. The LDL-C content was measured using the Fiedwall formula, whereas the MDA content was measure by using TBA-test. The observation of F2-isoprostane and Lp-PLA2 were exemplified by the procedure of Elisa's.

Results: The one way ANOVA test results between the three initial levels of atherosclerosis showed no significant differences in all lipid profiles both in serum and stress oxidation markers. However, the LSD test results projected significant differences in LDL levels in Ath-I compared to others. There was a significant difference $(p<0.0 I)$ in the serum of Lp-PLA2 content. The LSD test results displayed a significant increase in Lp-PLA2 enzyme levels since the Ath-II stage. Conclussion: The elevated levels of $L p-P L A 2$ also increased the atherogenecity of $L D L$, due to the increased inflammation, stress oxidation and elevated levels of Lp-PLA2, which were interconnected with proatherogenic loops.
\end{abstract}

Key words: Atherogenesis, Foam Cells, F2-Isp, LDL, Lp-PLA2, MDA

(Indonesian J Cardiol. 2019:40:282-289)

\footnotetext{
IBiology Department, Science and Technology Faculty, Universitas Islam Negeri (UIN) Maulana Malik Ibrahim Malang.

2 Medical Faculty of Brawijaya University, Malang.

${ }^{3}$ Diabetic Disease Center, Sutomo Hospital Surabaya

\section{Correspondence:}

Dr. Retno Susilowati, MSi,

Biology Department, Science and Technology Faculty, UIN Maulana Malik Ibrahim, Malang,

E-mail: retnosusilowatibms@gmail.com
}

\section{Introduction}

7 he process of atherogenesis begins with the formation of foam cells at the layer of subintima blood vessel walls. Atherosclerosis is the main cause of morbidity and mortality in the developing countries and becomes the primary etiology of cardio vascular diseases (CVD) such as coronary heart Disease (CHD), coronary arterial disease (CAD) dan cerebro vascular disease. Most CHDs are in the form of heart attack and most ischemia 
cases occurring in the brain are secondary effects of atherosclerosis 1,2 .

Atherosclerosis has many risk factors, among others: old age, smoking habit, obesity, hyper cholesterol, diabetes and high blood pressure. Hyper cholesterol is the main classical risk factor of atherosclerosis ${ }^{4}$ in addition to the age factor ${ }^{2}$, since $30-40 \%$ part of the atherosclerosis plaque is made from crystal cholesterol, ether cholesterol and lipid peroxide 3,5 . Oxidized Low Density Lipoprotein (oxLDL) instead of native Low Density Lipoprotein (nLDL) plays a major role in developing atherosclerosis from the early to the advanced stages, where an oxLDL plasma is expected to be able to be used as the marker in diagnosing atherosclerosis6. In contracts, a controversy has been identified. Hyper cholesterols, which was the main risk factor of atherosclerosis with the data in the field showing that $50 \%$ patients with atherosclerosis complication such as myocardial infarction did not have the classical risk factor $^{7,8}$ and in $35-40 \%$ of all CHD cases, the patients turned out showing that the total cholesterol content to be normal ${ }^{4,9}$. Therefore, a study on nonconventional biomarkers which mostly are found in serum but are closely related to the process of atherogenesis, especially at early stages that may improve proterogenic effects of LDL at the normal content during the early stage of atherosclerosis, is very important.

A lipoprotein-associated phospholipase A2 (LpPLA2) enzyme which is also called the platelet activating factor of asetilhydrolase (PAF-AH) is an enzyme produced and secreted by macrophages as a response to the lipid peroxide formation, especially the $\mathrm{PAF}$ compound and phosphocholine peroxide ${ }^{10}$. In the circulation, Lp-PLA2 is bound with apoB of the LDL ${ }^{11}$.

Various classical risk factors of atherosclerosis are positively correlated with the content of Lp-PLA2 plasma, such as hypercholesterol ${ }^{12}$, diabetes ${ }^{13,14}$, hypertension ${ }^{15}$, metabolic syndromme $1^{3,16}$, as well as symptomatic carotid atherosclerotic plaque17,18. The hypolipidemic drug decreases LP-PLA2 activity and concentration $^{19}$. Epidemiologic data show that LpPLA2 influences the cardiovascular disease (CVD), either at individuals' hypercholesterol and normal cholesterol $^{20,21}$ levels, yet its role and correlation with various risks factors and critical value of atherogenic Lp-PLA2 at the preliminary level have not been further studied.
Atherosclerosis is a chronic inflammation with lipid deposits in inflammatory cells, involving oxidative stress and endothelial dysfunction. The oxidized LDL (oxLDL) is a substrate of the Lp-PLA2 enzyme. As the Lp-PLA2 substrate, oxLDL can stimulate the expression and secretion of Lp-PLA2 ${ }^{11,22}$ so that Lp$\mathrm{PLA} 2$ is also classified as an oxidative stress marker23. Malonyl dialdehyde (MDA) and F2-Isoprostan (F2Isp) are known as common markers of oxidative stress because they are not only generated from arachidonic acid metabolism through the cyclooxygenase pathway, but also act as a lipid peroxide of linoleic acid and docohexanoic acid24. MDA and F2-Isp can be found in tissues as well as in plasma. F2-isoprostan is the best in vivo oxidation marker to date, because it is noninvasive and has high specificity ${ }^{25}$. People with atherosclerosis risk factors have shown an increase in F2-Isp include hypercholesterolemia ${ }^{26}$, diabetes ${ }^{25}$ and hypertension ${ }^{27}$. Like Lp-PLA2, measurements of MDA and F2-Isp levels in plasma in advanced atherosclerosis also portrays a significant increase $26,28,29,30$. Observation in rats with combination of hyper cholesterol feeding treatment and duration of eating reported that Lp-PLA2 aorta was not significantly different. However, serum levels of Lp-PLA2 indicated significant differences. In addition, the rate of serum elevation has occurred earlier than the increase in the number of foam cells $s^{31}$.

Based on previous research results, it is necessary to conduct further study on the harmful loops caused by LpPLA2 serum activity in the early stages of atherogenesis, depending on the different number of foam cells. This present research is intended to observe the changes the Lp-PLA2 enzyme contents, lipid profiles, and oxidation stress in the serum at the different stages of atherogenesis, as shown at the different number of foam cells resulted by high lipid diet in different times.

\section{Methods}

Animal Housing. The selected experimental animals in this research were male rats (Rattus norvegicus) with the age of 6-8 weeks, and the weight of 150-200 grams. The rats were obtained from CV. Gamma Scientific Biolab Malang. The materials for making hyperlipidemic foods were BR1(45\%, P.T. Wonokoyo Corporation), cholesterol ( $2 \%$, sigma Aldrich), folic acid (0,2\%, sigma 
Aldrich), lard (7,5\%, extracted from fresh pork adipose tissue), butter (5\%) and wheat flour $(22,5 \%$, CV. Bogasari). The animals were kept under 12-hour bright and 12-hour dark conditions, and foods and drinks were given in ad libitum. This research had obtained an ethical clearance from the Medical Faculty, Universitas Brawijaya, Malang, Indonesia, No. 0313/EC/KEPKS3-JK/11/2010).

Experimental Design. In this research, a Post Test Control Group Design was employed. Thirty rats at the age of 6-8 weeks with each weight of 150-200 grams were divided into 2 groups, where the control group were given normal foods (BR1) and the experimental one with the hyperlipidemic foods for 2,8 and 12 weeks periods ( 5 rats for each period), in order to obtain variations in the atherosclerosis development. At the end of the treatment, the serum of lipid profiles (covering the contents of the total cholesterol (TC), Triglycerides (TG), Low Density Lipoprotein (LDL), High Density Lipoprotein (HDL), Lipoprotein phospholipase A2 (LpPLA2), F2-Isoprostane (F2-Isp), Malonil Dealdehid (MDA) and the number of foam cells (FC) in aorta tissue were investigated. The data on the number of foam cells were made in three different levels of atherogenesis, namely atherogenesis level 1 (Ath-I), level 2 (Ath-II) and level 3 (Ath-III).

Sample Preparation and Assay Variable in Serum. At the end of the treatment, in order to extract the blood and blood vessels, the rats were anesthetized. The blood sample was taken from the heart, and then centrifuged in $3000 \mathrm{rpm}$ for 10 minutes. The serums produced were soon kept under the temperature of $-20^{\circ} \mathrm{C}$ before being used. The LDL-C content was measured with the Fiedwall formula; the MDA with the TBA test method were observed using a spectrophotometer with the wave length of $530.6 \mathrm{~nm}$. Further, the F2-Isp were examined using F2-isoprostant Immunoassay Kit (Direct 8-iso-Prostaglandin Fó Enzyme Immunoassay Kit, Assay Design with the catalog number of 900901). The observation followed the procedures stated in the product and was made using a spectrophotometer with the wavelength of $405 \mathrm{~nm}$. Lp-PLA2 was measured using the Sandwhich Ellisa method, examined with Elisa reader at the $\lambda 450 \mathrm{~nm}$ by following the procedure stated in the product (LpPLA2 Sandwich Elisa Kit produced by Cusabio Biotech CO., Ltd., with catalog number of CSB-E08320r).

Preparing the Aorta Tissue and Foam Cells Examination. The aorta blood vessels near the heart were cut for $1.5 \mathrm{~cm}$ and were washed using PBS, then were kept in the freezer at the $-20^{\circ} \mathrm{C}$ to make preparation of the fresh frozen section. The frozen aorta were crosscut with the thickness of $5 \mu \mathrm{m}$ using cryo cut. The prepared materials were kept at $-4^{\circ} \mathrm{C}$ and then stained with RedO and HE Oil. Examination was made on one cycle of the cross-cut aorta using the light microscope with the magnification of $40 \times 10$.

Statistical Analysis. A one way ANOVA test was employed to test the effects of the atherogenesis levels on all variables in the serums (the contents of TC, TG, LDL, HDL, F2-Isp, MDA and Lp-PLA2). A Least Significant Difference (LSD) test was exercised to know the pair-wise comparison of the treatment's mean with or without significant difference. The ANOVA and LSD tests were done using SPSS 16.0 computation software.

Table 1. Lipid Profiles in the Rat's Blood Serums at Various Stages of Atherogenesis

\begin{tabular}{|c|c|c|c|c|}
\hline $\begin{array}{c}\text { Stages of atherogenesis, } \\
\text { Cells/ field of view) }\end{array}$ & $\begin{array}{c}\text { TC } \pm \text { STDEV } \\
(\mathrm{mg} / \mathrm{dL})\end{array}$ & $\begin{array}{c}\mathrm{TG} \pm \text { STDEV } \\
(\mathrm{mg} / \mathrm{dL})\end{array}$ & $\begin{array}{l}\mathrm{LDL} \pm \text { STDEV }(\mathrm{mg} / \\
\mathrm{dL}\end{array}$ & $\mathrm{HDL} \pm \operatorname{STDEV}(\mathrm{mg} / \mathrm{dL})$ \\
\hline Ath-I & $125.11 \pm 20.77$ & $110.44 \pm 19.26$ & $74.33 \pm 21.03$ & $28.33 \pm 5.33$ \\
\hline Ath-II & $148.19 \pm 29.49$ & $121.10 \pm 16.76$ & $97.25 \pm 27.82$ & $26.75 \pm 3.29$ \\
\hline Ath-III & $158.40 \pm 32.84$ & $128.60 \pm 18.99$ & $106.88 \pm 28.39$ & $25.80 \pm 2.05$ \\
\hline Anova test & $\mathrm{p}>0.05$ & $\mathrm{p}>0.05$ & $\mathrm{p}>0.05$ & $\mathrm{p}>0.05$ \\
\hline \multicolumn{5}{|c|}{ LSD test } \\
\hline Ath-I vs Ath-II & $\mathrm{p}>0.05$ & $\mathrm{p}>0.05$ & $\mathrm{p}<0.05$ & $\mathrm{p}>0.05$ \\
\hline Ath-I vs Ath-III & $\mathrm{p}<0.05$ & $\mathrm{p}>0.05$ & $\mathrm{p}<0.05$ & $\mathrm{p}>0.05$ \\
\hline Ath-II vs Ath III & $\mathrm{p}>0.05$ & $\mathrm{p}>0.05$ & $\mathrm{p}>0.05$ & $\mathrm{p}>0.05$ \\
\hline
\end{tabular}


Indonesian Journal of Cardiology

Table 2. F2-Isp, MDA and of Lp-PLA2 Profiles in the Rat's Blood Serum at Various Stages of Atherogenesis

\begin{tabular}{lccc}
\hline $\begin{array}{c}\text { Stages of } \\
\text { atherogenesis, Cells/ field of } \\
\text { view) }\end{array}$ & $\begin{array}{c}\text { Mean Content of the F2-Isp } \\
\text { Serum } \pm \text { STDEV (ng/mL) }\end{array}$ & $\begin{array}{c}\text { Mean Content of MDA Serum } \pm \\
\text { STDEV (ng/mL) }\end{array}$ & $\begin{array}{c}\text { Mean Content of Lp-PLA2 } \\
\text { Serum } \pm \text { STDEV }(\mathrm{ng} / \mathrm{mL})\end{array}$ \\
\hline Ath-I & $172.38 \pm 38.19$ & $2.388 \pm 0.512$ & $158.81 \pm 50.10$ \\
Ath-II & $188.98 \pm 45.02$ & $2.756 \pm 1.567$ & $212.28 \pm 44.43$ \\
Ath-III & $218.15 \pm 33.37$ & $3.618 \pm 2.052$ & $255.14 \pm 28.03$ \\
Anova Test & $\mathrm{p}>0.05$ & $\mathrm{p}>0.05$ & $\mathrm{p}<0.01$ \\
& & & $\mathrm{p}<0.01$ \\
Ath-I vs Ath-II & $\mathrm{p}>0.05$ & $\mathrm{p}>0.05$ & $\mathrm{p}<0.01$ \\
Ath-I vs Ath-III & $\mathrm{p}>0.05$ & $\mathrm{p}>0.05$ & $\mathrm{p}>0.05$ \\
Ath-II vs Ath III & $\mathrm{p}>0.05$ & $\mathrm{p}>0.05$ & \\
\hline
\end{tabular}

non-significant $(\mathrm{p}>0.05)$; significant $(\mathrm{p}<0.05)$; very-significant $(\mathrm{p}<0.01)$

\section{Results}

The content of Lipid profile, oxidation level of LpPLA2 serum enzyme at different atherogenic levels

The number of foam cells observed in the frozen slices of blood vessels in a full circle has a range between 2-146 foam cells. From these data, three different levels of atherogenesis were identified, they were categorized into level 1 (Ath-I, less than 50 foam cells, 17.33 \pm 11.22 cells), level 2 (Ath-II, between 50 to less than 100 foam cells, $68.00 \pm 13.64$ cells) and level 3 (Ath-III, more than 100 foam cells, $124.2 \pm 18.50$ cells). The ANOVA test results showed that the number of foam cells at the three levels of atherosclerosis differed very significantly ( $p<0.01)$, as well as the results of all mean comparisons at the three levels of atherosclerosis using the LSD test.

One way ANOVA and LSD test results showed that all TC, TG and HDL lipid profile contents did not show any significant difference $(\mathrm{p}<0.05)$ among the three levels of atherogenesis. While the results of statistical tests on LDL levels showed that, even though the ANOVA test results did not show a significant difference, however LSD test showed that Ath-I was significantly different $(\mathrm{p}<0.05)$ from the others (Table 1). One way ANOVA and LSD test also did not identify differences in oxidation stress levels on MDA or F2-Isp parameters ( $p>0.05)$ among the three levels of atherogenesis. ANOVA test of LpPLA2 level in serum projected a very significant difference $(\mathrm{p}<0.01)$. It was in accordance with the LSD test results that displayed a significant difference between the contents of Lp-PLA2 in the Ath-I, and those of Ath-II and Ath-III. However, no significant difference occurred between Ath-II and of Ath-III (Table 2).

\section{Discussion}

The three levels of atherogenesis in this study showed no significant difference in lipid profiles. This was due to the fact that these three stages are the early stages of atherogenesis. However, the three levels of atherogenesis show a tendency that there is an increase in lipid profile of TC, TG and LDL. The LSD test results projected that the LDL content in Ath-III was significantly higher than Ath-I and Ath-II. The HDL content inclined to be inversely proportional to the levels of atherogenesis. This is also the case of oxidative stress levels indicated by the tendency of elevated levels of F2-Isp and MDA along with the increased levels of atherogenesis in blood vessels.

It cannot be denied that the material deposited in blood vessel walls in foam cells and atheroslerotic plaque in individuals with normal cholesterol or hypercholesterolemia are cholesterol molecules. Therefore, it can be ascertained that this is another factor which increases the cholesterol reactivity in the blood circulation so as to trigger an atherogenic inflammatory reaction even if the contents are normal. Among the parameters, only Lp-PLA2 serum content that has shown significant difference since the initial stage and the content up to stage of Ath-II has been stabilized in this study. The content of Lp-PLA2 in the serum of $212.28 \pm 44.43 \mathrm{ng} / \mathrm{ml}$ (Ath-II) has been identified significantly different from that of the Ath-I (158.81 \pm 


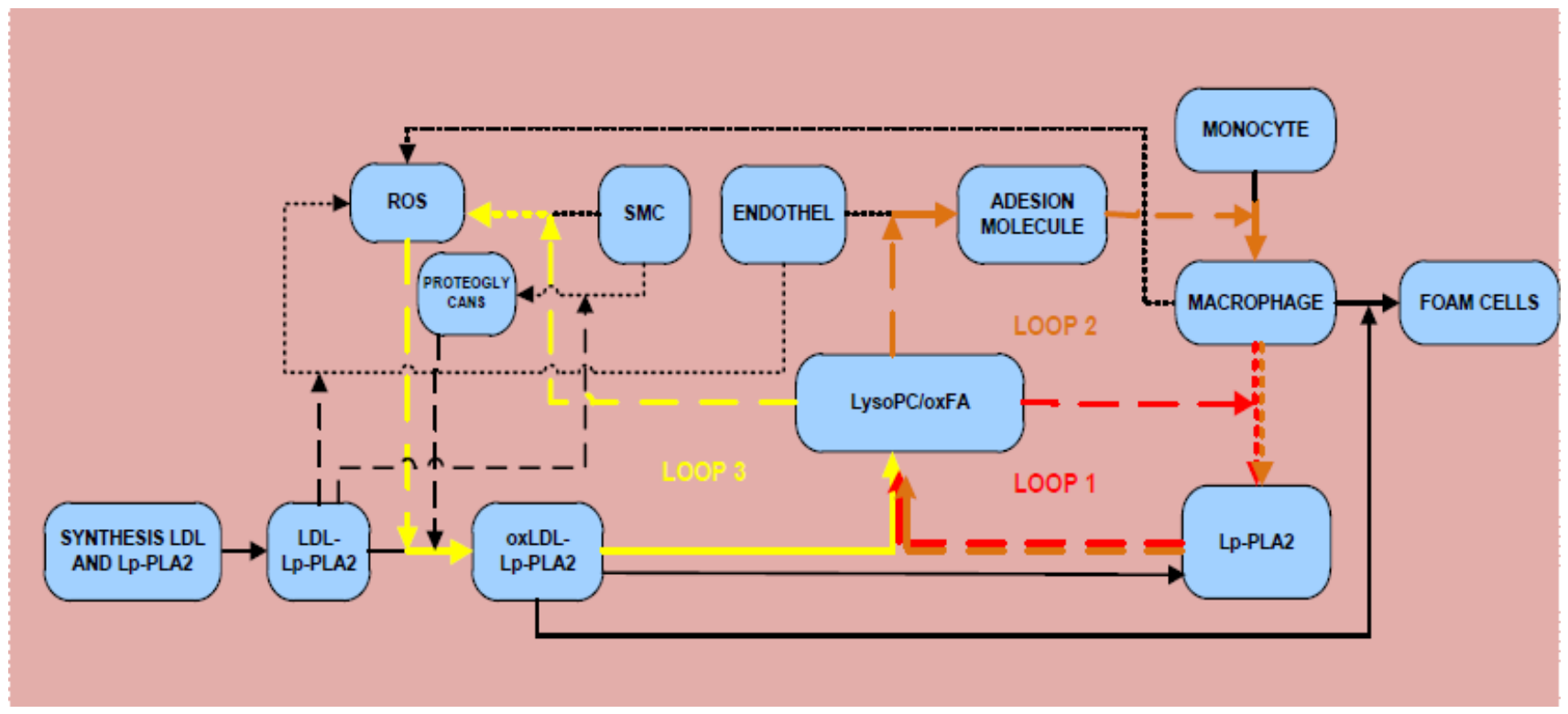

Figure 1. Three Dangerous Proatherogenic Loops caused by Lp-PLA2 Enzyme

Notes:

LDL: Low Density Lipoprotein, Lp-PLA2: Lipoprotein-Associated Phospholipase A2, LDL-Lp-PLA2: Complex LDL-LpPLA2. oxLDL-Lp- PLA2: Complex LDL-Lp-PLA2 Oxidized, LysoPC: Lyso Phosphatidylcholin, oxFA: Oxidized Fatty Acid, oxLDL: Oxidized Low Density Lipoprotein, oxPC: Oxidized-Phosphatidylcholine, ROS: Radical Oxygen Species, SMC: Smooth Muscle Cell

$50.10 \mathrm{ng} / \mathrm{ml})$ and it increased at the Ath-III (255.14 $\pm 28.03)$. This condition due to the possibility of the Lp-PLA2 enzyme activity which was able to improve the characteristic of the atherogenecity of the LDL cholesterol so that it is deposited at the blood vessel walls even though the cholesterol content in the serum was still at the normal category.

A high increase was found in the content of Lp-PLA2 serum above $200 \mathrm{ng} / \mathrm{ml}$ at Ath-II in the observation of atherogenesis and a relatively stable increase and then a slowly increase at the next period though the addition in the content was not significantly different. At the AthIII period, it was projected that the content has been able to push ahead a significant level of atherogenesis. It might be that the content of Lp-PLA2 would rise to the next level of atherogenesis to reach its maximal content. A similar phenomenon also happened to the research by Shi et al. using experimental animal pigs with diabetes/ hypercholesterol11. The content of Lp-PLA2 serum in the research had increased sharply since the observation at the fourth week and was still high without any significant increase at the observations from the $12^{\text {th }}$ to the $24^{\text {th }}$ weeks.
In regards to the materials deposited either in the foam cells or atherosclerotic plaques that were LDL, the increase of the differences in the number of foam cells occurred more rapidly than the increase in the LDL. The Lp-PLA2 as a lipase enzyme plays a functionally important role in the process of atherogenesis as it is closely related to LDL.

Lp-PLA2 levels correlated with LDL levels and both correlated with the number of foam cells either directly or indirectly. Thus, it is predictable that the enzyme of Lp-PLA2 becomes the key molecule for the process of aterogenesis carrier of LDL accumulation in the foam cell. This condition also in line with Goncalves's et.al's finding, suggesting that the Lp-PLA2 level is significantly determinative in correlation with LysoPC levels as well as inflammatory cytokine32. The results of this study indicated no correlation between formation of foam cells with both oxidation stress markers; MDA and F2Isp. The findings suggested that oxidative stress acted not directly on foam cells formation, but depended on LPPLA2 enzyme activity. This is consistent with the finding of Stafforini's et.al that showed the release of F2Isp from esterified phospholipids that was also catalyzed by both intracellular and plasma Lp-PLA2 ${ }^{33}$. 
Indonesian Journal of Cardiology

The potential of Lp-PLA2 as the promoter of LDL atherogenesis was not only supported by this research results, but also by various other researches. If observed in detail, Lp-PLA2 showed its role in the whole process of atherogenesis that might cause the three dangerous pro-atherogenic loops (Figure 1).

Phosphatydilcholine (PC) is a main phospholipid, the composer of cell membrane and LDL ${ }^{34}$. Oxidation by free radicals to oxLDL results in oxPC that becomes the substrate of the Lp-PLA2 enzyme activities. LpPLA2 is bound to be apoB of LDL11 (Shi et al. 2007), hydrolyzing an oxPC to produce LisoPC and oxFA ${ }^{21,35}$. In an analogy of a production machine and the foam cells as the product of atherogenesis, Lyso-PC causes the formation of three dangerous proatherogenic loops that may be categorized into 3 loops:

Loop 1. The activator of the atherogenesis process (positive feedback of Lp-PLA2 production)

LysoPC induced the macrophages so that it produced inflamatory cytocin of TNF- $\alpha$, IL- 6 and IL$1 \beta$, playing the role as an autocrine as well as stimulating macrophages to produce Lp-PLA2 11,32.

Loop 2. The operator of the atherogenesis process (Positive feedback of proatherogenic inflammatory reaction)

LysoPC stimulated the endothel to excrete its adhesive molecules ${ }^{21,36,37}$ which then facilitated the migrate of monocytes from the circulation to subendothel, assisting the development of monicytes into macrophages and foam cells ${ }^{11}$.

Loop 3. The generator of the atherogenesis process (positive feedback of ROS production).

In addition to its role as the source of Lp-PLA2, macrophages also acted as potential sources of ROS so that the formation reaction of oxLDL and oxPC as the substrate of Lp-PLA2 might produce lysoPC as the derivative actor for the Proatherogenic to continually occur. LysoPC also stimulated SMC of blood vessel walls to produce ROS37. The three loops above have facilitated the occurrence of LDL oxidation, inflammation reaction, ROS formation and provision of Lp-PLA2 enzyme which all are keys to form foam cells and to support atherogenesis to continue to happen although the LDL content was at the normal level.

\section{Conclussion}

Studies have shown that the presence of the Lp-PLA2 serum can be used as a basis to explain the presence of CVD patients with normal cholesterol but with increasing Lp-PLA2 enzyme. The presence of Lp-PLA2 significantly improves proatherogenic characteristic of LDL. The serum content of Lp-PLA2 for more than $200 \mathrm{ng} / \mathrm{ml}$ is a critical content that can improve the atherogenic characteristic of LDL. The increased levels of Lp-PLA2 has caused an increased atherogenecity of LDL, due to the increased inflammation, stress oxidation and elevated levels of Lp-PLA2, which act as the proatherogenic factors.

\section{Ethical Clearance}

This study was approved by the institution's ethic committee.

\section{Conflict Of Interest}

None

\section{Publication Agreement}

The authors of this article give permission to Indonesian Journal of Cardiology to publish this article if this article is accepted

\section{Acknowledgement}

Special gratitude is extended to the Directorate General for Higher Education, the Ministry of the National Education that has funded this research through DIPA of Universitas Brawijaya, Malang, Indonesia.

\section{List of Abbreviations}

CAD: Coronary Artery Disease

CVD: Cardiovascular Diseases

F2-Isp: F2-Isoprostane

FC: Foam Cells

HDL: High Density Lipoprotein

PAF-AH: platelet activating factor of asetilhydrolase

LDL: Low Density Lipoprotein

Lp-PLA2: lipoprotein-associated phospholipase A2 
MDA: Malonyl Dialdehyde

nLDL: native Low Density Lipoprotein

oxLDL: Oxidized Low Density Lipoprotein

\section{References}

1. Gotto AM, 2004. Contemporary Diagnosis and Management of Lipid Disorder, Handbooks in Health Care Co, Pennsylvanis, USA pp. 1-53.

2. Stocker R and Keaney JF, 2005. Oxidative Stress and Atherosclerosis. In Localzo J. (ed) Molecular Mechanisms of Atherosclerosis. Taylor \&Francis. London-New York pp. 82-114.

3. Shah PK, 2007. Molecular Mecha nisms of Palque Instability. Current Opinion in Lipidology 18: 492499.

4. Ballantyne CM, O'Keee JH, Gotto AM, 2007. Dyslipidemia Essentials. Physician Press, New York. p. 1-63.

5. Howlett GJ and Moore KJ, 2006. Untangling the Role of Amyloid in Atherosclerosis. Current Opinion Lipidology 17: 541-547.

6. Ishigaki Y, Oka Y, Katagiri H, 2009. Circulating Oxidized LDL: a Biomarker And a Pathogenic Factor. Current Opinion in Lipidology 5: 363-369.

7. Anand DV, Lahiri A and Lipkin D, 2003. EBCT coronary calcium imaging for the early detection of coronary artery disease in asymptomatic individuals, J Cardiol 79: 10-17.

8. Miyamoto $\mathrm{T}$, Yumoto $\mathrm{H}$, Takakashi $\mathrm{Y}$, Davey M, Gibson FC and Genco CA, 2006. Patogen accelerated Atherosclerosis Occur Early after Exposure and Can be Prevented via Immunization. Infection and Immunity 74: 1376-1380.

9. Ferri N, Paoletti R and Corsini A, 2006. Biomarker for Atherosclerosis: Pathophysiological Role and Pharmacological Modulation, Current Opinion in Lipidology17: 495-501.

10. Elstad MR, Stafforini DM, Prescott SM, McIntyre TM and Zimmerman, 1991. Human Macrophages Secrete Platelet-Activating Factor Acetylhydrolase. Chest 99 9S-10S.

11. Shi Y, Zhang P, Zhang L, Osman H, Mohler ER, Macphee C, Zalewski A, Postle A, Wilensky, 2007. Role of Lipoprotein-associated Phospholipase A2 in Leukocyte Activation and Inflammatory Responses. Atherosclerosis 191: 54-62.
12. Moriarty and Gibson, 2005. Effect of Low Density Lipoprotein Apheresis on Lipoprotein Associated Phospholipase A2. Am J Cardiol. 95: 1246-1247.

13. Noto H, Chitkara P and Raskin P, 2006. The Role of Lipoprotrein-Associated Phospholipase A2 in the Matabolic Syndrome and Diabetes. Journal of Diabetes ang the Complication. 20: 343-348.

14. Yang C, Chen H, Huang MT, Raya JL, Yang J, Chen C, Gaubatz JW, Pownall HJ, Taylor AA, Ballatyne CM, Jenniskens FA and Smith CV, 2007. Proapoptotic Low Density Lipoprotein Subfraction in TRype II Diabetes. Atherosclerosis. 193: 283-291.

15. Gorelick PB, 2008. Lipoprotein Assocoated phospholipase A2 and Risk of Stroke. Am. J. Cardiol. 101: 34F-40F.

16. Filippatos TD, Gazi IF, Liberopoulos VG, Elisaf MS, Tselepis AD and Kiortis DN, 2006. The Effect of Orsilat and Fenofibrate, alone or Combination, on Small dense LDL and Lipoprotein-associated Phospholipase A2 in Obese patients with Metabolic syndrome. Atherosclerosis. 193:428-437.

17. Persson M, Hedblad B, Nelson JJ, Berglund G, 2007. Elevated Lp-PLA2 Levels Add Prognostic Information to the Metabolic Syndrome on Incidence of Cardiovascular Events Among MiddleAged Nondiabetic Subjects, Atheroscler Thromb Vasc Biol 10:1411=1416.

18. Mannheim D, Herrmann J, Versari D, Go“ssl M, Meyer FB, McConnell JP, Lerman LO, Lerman A, 2008. Enhanced Expression of Lp-PLA2 and Lysophosphatidylcholine in Symptomatic Carotid Atherosclerotic Plaques, Stroke, 2008;39:14481455.

19. Silva IT., Mello AP., Damaceno RT. 2011. Antioxidant and inflammatory aspects of lipoprotein-associated phospholipase A2 (Lp-PLA2 ): A Review Lipids in Health and Disease, 10:170.

20. Gustone FD, 1996. Fatty Acid and Lipid Chemistry. Blackie Academic \& Professional, New York. p. 81.

21. Iribarren C, 2006. Lipoprotein-Associated Phospholipase A2 and Cardiovascular Risk State of the evidence and Future Directions. Arteriosclerosis Thromb Vasc Biol. 26:5-6.

22. Wang Y and Oram JF, 2007. Unsaturated Fatty Acids phosphorylate and Destabilize ABCA1 Through a Protein Kinase C $\delta$ Pathway. Journal of 
Lipid Research 48: 1062-1968.

23. Paramo JA, Rodriguez JA and Orbe J, 2006. Integrating Soluble Biomarkers and Imaging Technologies in The Identification of Vulnerable Atherosclerotic Patients. Biomarker Insight 1: 165173.

24. Halliwell B, Guteridge JMC, 1999. Free Radicals in Biology and Medicine $3^{\text {rd }}$ ed., Oxford University Press, NewYork. pp. 27-250.

25. Devaraj S, Hirany SV, Burk RF and Jialal I, 2001. Divergence between LDL Oxidative Susceptibility and Urinary F2-Isoprostanes as Measures of Oxidative Stress in Type 2 Diabetes. Clinical Chemistry 11: 1974-1979.

26. Reilly MP, Pratico D, Delanty N, DiMinno G, Tremoli E, Rader D, Kapoor S, Rokach J, Lawson J, FitzGerald G, 1998. Increased Formation of Distinct F2 Isoprostanes in Hypercholesterolemia, Circulation 98: 2822-2828.

27. Touyz RM and Schiffrin EL, 2007. Oxidative Stress and Hypertension. In Hotzman (ed) Atherosclerosis and Oxidant Atress : A New Perspective. Springer pp. 51-77.

28. Pezeshkian M, Nouri M, Zahraei M, Afrasiabi A and Abadi NA, 2001. Study of MDA, Antioxidant Vitamins, Lipoproteins Serum Levels and Anthropometry Parameters in Coronary Artery Disease Patients. Medical Journal of Islamic Academy of Sciences. 14: 5-8.

29. Kametsu Y, Kitagawa Y, Sekiyama $S$ and Takagi $S$, 2005. Increase in Plasma MalondialdehydeModified Low-Density Lipoprotein in patients with Atherothrombotic Cerebral Infarction. Tokai J Exp Clin Med 30: 171-176.

30. Mogadam RAP, Nemati A and Baghi AN, 2008. Serum MDA as a Diagnostic's Biomarker in Stable Coronary Heart Disease. Research Journal of Biological Sciences 3: 206-210.

31. Susilowati R, Sargowo D, Indra R, Tjokroprawiro A, Widyarti S, 2012. Korelasi antara Kadar LpPLA2, MDA, F2-Isp diserum dan Jaringan Aorta dengan jumlah sel busa dalam Proses aterogenesis pada Tikus Wistar, Jurnal Kardiologi Indonesia (33): 227-35.

32. Goncalves I, Wdsfeldt A, Young N K, Grufman H, Berg K, Bjorkbacka H, Nitulescu M, Persson A, Nilson M, Prehn C, Adamski J, Nilsson J, 2012.
Lysophosphatidylcholine in Human Atherisclerotic Plaque Inflammation, Atheroscler Thromb Vasc Biol.: 1505-1512.

33. Stafforini D, Sheller JR, Blackwell TS, Sapirstein A, Yull FE, Mcientyre TM, Bonventre JV, Prescott SM and Roberts LJ, 2005. Release of F2-isoprostanes from Esterified Phospholipids Is Catalyzed by Intracellular and Plasma Platelet-activating Factor Acetylhydrolases. The Journal og Biological and Chemistry. 28: 4616-4623.

34. Karabina SA, Brocheriou I, Naour GL, Agrapart M, Durand H, Gelb M, Lambeau G and Ninio E, 2006. Atherogenic Properties of LDL Particles Modified by Human Group X Secreted Phospholipase A2 on Human Endothelial Cell Function, The Faseb Journal 20: E1890-E1900.

35. Liao W, Liu C and Wang C, 2008. Detection of lipoprotein-associated phospholipase A2 using a nano-iridium particle catalyst-based biosensor, SensorsandActuators B (134): 993-999.

36. Feistein SB, 2008. Vascular Imaging. Feinstein (ed). Non Invasive Surrogate Marker of Atherosclerosis, Informa Healthcare, Informa KU Ltd, London pp. 85-87.

37. Zalewski A and Macphee C, 2005. Role of Lipoprotein-Associated Phospholipase A2 in Atherosclerosis: Biology, Epidemiology, and Posible Thearpeutic Target, Journal of The American Heart Assocoation 25: 923-931. 